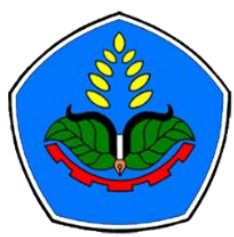

AGROPROSS

National Conference

Proceedings of Agriculture

\section{Proceedings: \\ Peran Teaching Factory Di Perguruan Tinggi Vokasi Dalam \\ Mendukung Ketahanan Pangan Pada Era New Normal}

Tempat : Politeknik Negeri Jember

Tanggal : 8-9 Juli 2020

\section{Publisher:}

Agropross, National Conference Proceedings of Agriculture

ISBN : 978-623-94036-6-9

DOI : 10.25047/agropross.2020.41

\title{
Karakteristik Bakteri Rhizobium japonicum Bintil Akar Kedelai pada Cekaman Salinitas Bertingkat
}

\author{
Author(s): Risma Wakhidatur Rohmani ${ }^{(1)}$; Iqbal Erdiansyah $^{(1)}$; Djenal $^{(1)}$ \\ (1) Program Studi Teknologi Produksi Tanaman Pangan, Jurusan Produksi Pertanian, Politeknik Negeri Jember \\ * Corresponding author: rismawahid35@gmail.com
}

\begin{abstract}
The increase in the surface temperature of the earth has an impact on rising sea levels to the land, this is what causes the salts contained by seawater to experience sedimentation in the soil through which it passes. Salted soybean plants can reduce crop production because dissolved salts can reduce the potential of soil solution so that plants experience water shortages. Specific technology used to support the growth and yield of soybean plants in saline land is the use of biological fertilizers, one of which comes from Rhizobium japonicum. Rhizobium japonicum is a rhizosphere bacterium that is able to break down free nitrogen in the air into elements that are able to be absorbed by plants. Nitrogen is a very important nutrient in the process of plant photosynthesis to produce photosynthates that are useful for optimal growth and production. This study aims to isolate and characterize the Rhizobium japonicum bacteria at a certain level of salinity in the $Y E M A+$ Congo Red media, this research was conducted in June 2019 to September 2019 at the Jember Polytechnic Biosciences Laboratory. This research was conducted using a non-parametric design with various levels of salinity stress in the media, namely: 0 ppm, 1000 ppm, 2500 ppm, $4000 \mathrm{ppm}$, and $8000 \mathrm{ppm}$. The results showed that the colonies of Rhizobium japonicum were white to pink with a convex shape that was white to pink and had a cell size of $2 \mu-4 \mu$.
\end{abstract}

Keyword:

Rhizobium

japonicum;

Cekaman

Salinitas;

Fiksasi

Nitrogen.;

\begin{abstract}
Kata Kunci:
ABSTRAK

Rhizobium

Kenaikan suhu permukaan bumi berimbas pada naiknya permukaan air laut ke daratan, hal inilah japonicum; yang menyebabkan garam-garam yang dikandung oleh air laut akan mengalami sedimentasi di tanah yang dilewatinya. Tanaman kedelai yang tercekam salin dapat menurunkan hasil produksi tanaman karena garam yang terlarut dapat menurunkanpotensial larutan tanah sehingga tanaman

Cekaman

Salinitas; mengalami kekurangan air. Teknologi khusus yang digunakan untuk menunjang pertubuhan dan hasil tanaman kedelai di lahan salin adalah penggunaan pupuk hayati, yang salah satunya berasal

Fiksasi Nitrogen dari Rhizobium japonicum.Rhizobium japonicum merupakan bakteri rizosfer yang mampu menguraikan nitrogen bebas di udara menjadi unsur yang mampu terserap oleh tanaman. Nitrogen adalah unsur hara yang sangat penting dalam proses fotosintesis tanaman untuk menghasilkan fotosintat yang berguna untuk pertumbuhan dan produksi yang optimal. Penelitian ini bertujuan untuk mengisolasi dan mengkarakterisasi bakteri Rhizobium japonicum pada tingkat salinitas tertentu pada media YEMA+Congo Red,penelitian ini dilakukan pada bulan Juni 2019 sampai dengan September 2019 di Laboratorium Biosain Politeknik Negeri Jember. Penelitian ini dilakukan dengan menggunakan rancangan non parametrik dengan berbagai macam tingkat cekaman salinitas pada media yaitu: 0 ppm, 1000 ppm, 2500 ppm, 4000 ppm, dan 8000 ppm. Hasil penelitian menunjukkan koloni bakteri Rhizobium japonicum berbentuk bulat cembung berwarna putih sampai merah muda dan ukuran sel $2 \mu-4 \mu$.
\end{abstract}




\section{PENDAHULUAN}

Jumlah penduduk di Kabupaten Banyuwangi setiap tahun terus meningkat,hal ini berbanding lurus dengan peningkatan konsumsi pangan yang terus meningkat pula. Kedelai merupakan tanaman yang mengandung protein nabati yang tinggi, dengan harga yang cukup terjangkau kedelai sangat digemari oleh semua kalangan masyarakat, hal ini lah yang menyebabkan permintaan produk kedelai terus meningkat baik untuk industri pangan ataupun industri pakan. Produksi tanaman kedelai di Kabupaten Banyuwangi sejak tahun 2015 hingga 2017 terus mengalami penurunan hasil yang signifikan, hal ini karena kenaikan air laut ke daratan yang disebabkan oleh naiknya suhu di bumi, sehingga garam-garam yang dikandung oleh air laut akan mengalami sedimentasi di tanah yang dilewatinya (BPS, 2016). Menurut Aini, dkk (2014), tanah yang dikategorikan sebagai tanah salin adalah ketika tanah tersebut mampu menghantarkan arus listrik dari ekstrak tanah yang dijenuhkan yaitu sebesar $>4$ $\mathrm{ds} / \mathrm{m}$.

Kemungkinan penyebab turunnya tingkat produksi kedelai nasional yaitu, (1) rendahnya tingkat produktivitas kedelai, (2) Rentan terhadap serangan organisme pengganggu tanaman (OPT), (3) kebijakan impor (perdagangan bebas) yang membuat harga kedelai nasional lebih mahal dibandingkan kedelai impor, (4) luas areal tanam kedelai yang semakin menurun setiap tahun kerana tidak adanya peremajaan lahan baru, (5) perkembangan teknologi budidaya tanaman kedelai yang masih rendah.

pertanian, namun hanya 729,9 ribu Hektar lahan potensial tersebut yang baru dimanfaatkan di bidang pertanian (Alihamsyah, 2014).

Penggunaan lahan dengan cekaman salinitas perlu digunakannya suatu teknologi khusus untuk menunjang pertumbuhan dan produksi tanaman kedelai. Salah satu caranya adalah menggunakan mikroorganisme. Bakteri rizosfer yaitu Rhizobium sp. yang merupakan bakteri yang hidup di sekitar akar tanaman yang memiliki banyak peran yaitu, sebagai biofertilizer yaitu, mampu menguraikan nitrogen bebas di udara menjadi unsur yang mampu terserap oleh tanaman sehingga dapat menunjang pertumbuhan tanaman(Bloemberg \& Lugtenberg, 2001). Isolasi bakteri Rhizobium di lahan salin merupakan cara untuk mendapatkan isolat bakteri yang toleran di lahan salin sehingga dapat dikembangkan menjadi dasar pembuatan pupuk hayati yang diharapkan mampu menjadi upaya dalam pemanfaatan lahan salin untuk pertanian.

\section{BAHAN DAN METODE}

Tempat penelitian ini dilaksanakan di Laboratorium Biosain Politeknik Negeri Jember, Kecamatan Sumbersari, Kabupaten Jember. Waktu pelaksanaan penelitian mulai bulan Juni 2019 sampai dengan September 2019. Bahan yang digunakan adalah bintil akar kedelai, $\mathrm{K}_{2} \mathrm{HPO}_{4}, \mathrm{MgSO}_{4}, \mathrm{CaCo}_{3}$, Manitol, Yeast Extracts, Agar, Akuades, Cristal violet, iodine, Alkohol 96\%, Safranin, Congo Red, Brom Thymol Blue, Air, kapas, tissue, korek api kertas label, Plastik, plastik wrapping, alkohol 70\%, alumunium foil.

Penelitian ini dilakukan dengan menggunakan rancangan non parametrik dengan berbagai macam tingkat cekaman salinitas pada media yaitu: 0 ppm, 1000 ppm, 2500 ppm, 4000 ppm, dan 8000 ppm. Data yang didapat dilakukan uji analisa kualitatif dan kuantitatif. Uji kuantitatif menggunakan teknik TPC (Total Plate Counting) dan uji kualitatif didapat dari pengamatn makroskopis dan mikroskopis.

Isolasi bakteri Rhizobium japonicum dari bintil akar kedelai dimulai dengan memilih sampel bintil akar kedelai keudian di pilih yang berwarna merah sampai kecoklatan seberat 1 gram. Bintil akar 
kemudian di bersihkan dan di sterilkan dengan $10 \mathrm{ml}$ larutan dettol $(5 \%, 3 \%, 1 \%)$ dengan cara di vortex masing-masing selama 2 menit. Selanjutnya di sterilkan dengan $10 \mathrm{ml}$ aqadest steril sebanyak $3 \mathrm{kali}$ masing-masing selama 1 menit. Bintil akar yang sudah steril dihancurkan didalam tabung reaksi kemudian dialakukan pengenceran hingga $10^{5}$ lalu diambil $0,1 \mathrm{ml}$ larutan untuk diinokulasikan ke dalam media YEMA + Congo red yang juga sudah ditambah dengan garam $\mathrm{NaCl}$ sesuai dengan perlakuan.

Parameter pengamatan meliputi, jumlah koloni bakteri, kecepatan tumbuh bakteri, dan morfolgi bakteri. Data hasil pengamatan jumlah koloni dilakukan analisis menggunkan TPC (Total Plate Counting). jumlahkoloni /ml

$$
\begin{aligned}
& =\text { jumlahkoloni/cawan } \\
& \times \frac{1}{\text { vol.sampel }} \\
& \times \frac{1}{\text { F.Pengenceran }}
\end{aligned}
$$

\section{HASIL DAN PEMBAHASAN Tinggi Tanaman (cm)}

Berdasarkan hasil isolasi bakteri Rhizobium pada bintil akar tanaman kedelai di tanah salinDesa Tegaldlimo Kabupaten Banyuwangi pada cekaman salinitas bertingkat. dengan parameter pengamatan meliputi jumlah koloni bakteri, kecepatan pertumbuhan bakteri, dan morfologi bakteri. Berikut kumpulan dari keseluruhan parameter hasil eksplorasi bakteri

Tabel 1. Rangkuman Parameter Pengamatan

Perlakuan

\begin{tabular}{llllll}
\cline { 2 - 5 } Parameter & A0 (0 ppm) & $\begin{array}{l}\text { A1 (1000 } \\
\text { ppm) }\end{array}$ & $\begin{array}{l}\text { A2 (2500 } \\
\text { ppm) }\end{array}$ & $\begin{array}{l}\text { A3 (4000 } \\
\text { ppm) }\end{array}$ & $\begin{array}{l}\text { A4 (8000 } \\
\text { ppm) }\end{array}$ \\
\hline $\begin{array}{l}\text { Rerata jumlah } \\
\text { koloni bakteri }\end{array}$ & $3,11 \times 10^{6}$ & $1,01 \times 10^{7}$ & $4,62 \times 10^{6}$ & $3,49 \times 10^{7}$ & $2,51 \times 10^{6}$ \\
$\begin{array}{l}\text { Kecepatan } \\
\text { pertumbuhan } \\
\text { bakteri }\end{array}$ & $\begin{array}{l}\text { Fast } \\
\text { growing }\end{array}$ & $\begin{array}{l}\text { Fast } \\
\text { growing }\end{array}$ & $\begin{array}{l}\text { Slow } \\
\text { growing }\end{array}$ & $\begin{array}{l}\text { Fast } \\
\text { growing }\end{array}$ & $\begin{array}{l}\text { Slow } \\
\text { growing }\end{array}$ \\
$\begin{array}{l}\text { Morfologi } \\
\text { bakteri }\end{array}$ & $\begin{array}{l}\text { Bulat, rata, } \\
\text { cembung }\end{array}$ & $\begin{array}{l}\text { Bulat, rata, } \\
\text { cembung }\end{array}$ & $\begin{array}{l}\text { Bulat, rata, } \\
\text { cembung }\end{array}$ & $\begin{array}{l}\text { Bulat, rata, } \\
\text { cembung }\end{array}$ & $\begin{array}{l}\text { Bulat, rata, } \\
\text { cembung }\end{array}$ \\
$\begin{array}{l}\text { Penentuan } \\
\text { jenis gram }\end{array}$ & $\begin{array}{l}\text { Gram } \\
\text { negatif }\end{array}$ & $\begin{array}{l}\text { Gram } \\
\text { negative }\end{array}$ & $\begin{array}{l}\text { Gram } \\
\text { negatif }\end{array}$ & $\begin{array}{l}\text { Gram } \\
\text { negative }\end{array}$ & $\begin{array}{l}\text { Gram } \\
\text { negatif }\end{array}$ \\
\hline
\end{tabular}

Keterangan:

Fast Growing $=$ Tipe pertumbuhan cepat bakteri Rhizobium yang ditandai dengan warna isolat berubah menjadi kuning

Slow Growing $=$ Tipe pertumbuhan cepat bakteri Rhizobium yang ditandai dengan warna isolat berubah menjadi biru

\section{Jumlah Koloni Bakteri}

Pengamatan jumlah koloni bakteri dilakukan selama 72 jam. Perhitungan jumlah koloni dilakukan secara makroskopis dengan teknik TPC (Total
Plate Counter) yang dibantu dengan alat colony counter. Berdasarkan tabel 1 hasil isolat yang diinokulasikan kedalam media cekaman salinitas mengalami ketahanan terhadap tingkat salinitas yang tinggi, yaitu 
dengan masih didapatnya koloni bakteri yang tumbuh pada media dengan kadar $\mathrm{NaCl} 8000 \mathrm{ppm}$ atau setara dengan $16 \mathrm{ds} / \mathrm{m}$. jumlah koloni bakteri pada 8000 ppm adalah yang yang terkecil hal ini bisa diakibatkan karena bakteri rhizobium mengalami kondisi stres karena tingkat salinitas nya yang tinggi. Pada media dengan kandungan $\mathrm{NaCl} 4000$ ppm bakteri mampu tumbuh dengan jumlah koloni bakteri yang meningkat. Hal ini sesuai dengan pendapat Fuskhah (2007) bahwa bakteri Rhizobium yang ditumbuhkan pada media salin rendah kemudian ditingkatkan pada tingkat salinitas yang berangsurangsur tinggi dapat memperlihatkan ke toleran hingga pada tingkat tertentu.

Setelah dilakukan pengamatan jumlah koloni bakteri selama 3 hari atau 72 jam laju pertumbuhannya berbeda. Pada 12 jam pertama setelah bakteri di inokulasikan kedalam media koloni bakteri belum ada yang mengalami pertumbuhan hal ini dikarenakan rhizobium memasuki fase lag atau penyesuaian dimana mikroba hasil isolasi di lapang akan menyesuaikan dengan media tumbuh YEMA. Setelah 24 jam kemudian bakteri memasuki fase log dimana bakteri akan mulai tumbuh dan pertumbuhannya seimbang serta memasuki fase pertumbuhan yang maksimal. Fase ketiga yaitu 48 jam setelah inkubasi bakteri akan memasuki fase stasioner, dimana ph media, akumulasi nutrient di media akan mengalami penurunan sehingga pertumbuhan bakteri akan mengalami penurunan. Fase terakhir yaitu fase kematian dimana jumlah sel bakteri akan lebih banyak yang mati karena habisnya nutrien di media YEMA.

\section{Kecepatan Pertumbuhan Bakteri}

Pengamatan untuk kecepatan pertumbuhan bakteri dilakukan dengan menumbuhkan bakteri Rhizobium pada media selektif YEMA yang dikombinasikan dengan penambahan
Broom Thymol Blue (BTB) dan juga pengamatan berdasarkan jumlah koloni.
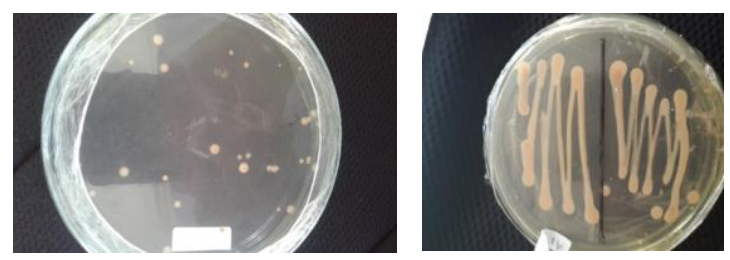

Gambar 1. Koloni Bakteri Rhizobium dalam Media YEMA dan congo Red

Hasil pengamatan laju kecepatan bakteri berdasarkan inokulasi kedalam media BTB menunjukkan bahwa pada media dengan kandungan $\mathrm{NaCl} 1000$ ppm merupakan tipe bakteri yang pertumbuhannya cepat (Fast Growing) karena warna isolat bakteri menjadi kuning selama masa pertumbuhan, sedangkan pada bakteri yang di inokulasikan di media dengan kandungan $\mathrm{NaCl} 2500$ ppm, 4000 ppm, dan 8000 ppm merupakan tipe bakteri yang pertumbuhannya lambat (Slow Growing) hal ini ditunjukkan dengan perubahan warna pada isolat bakteri menjadi biru.. Namun jika dilihat dari pertumbuhan koloni, bakteri dengan cekaman salin 4000 ppm mempunyai jumlah koloni terbanyak hal ini terjadi karena bakteri sudah mengalami adaptasi pada media dengan tingkat salinitas 4000 ppm yang mana walaupun bakteri tersebut memunculkan isolat berwarna biru pada medeia BTB tetapi bakteri tersebut dapat tumbuh secara cepat.
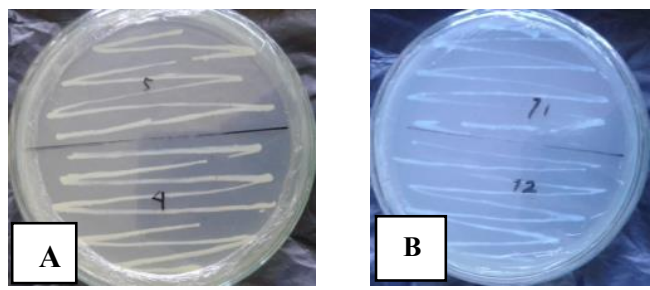

Gambar 2. Tipe Pertumbuhan Bakteri $\mathrm{A}=$ Fast Growing; $\mathrm{B}=$ Tipe Kecepatan Tumbuh Slow Growing 
Morfologi Bakteri

Tabel 2. Analisa Morfologi Bentuk Koloni Bakteri Rhizobium pada media cekaman salinitas

\begin{tabular}{ll}
\hline Penampkan Makroskopis Bakteri & Morfologi Koloni Bakteri Rhizobium \\
\hline Bentuk Koloni & Bulat \\
Bentuk Tepian Koloni & Rata \\
Bentuk Elevasi Koloni & Cembung \\
Warna Koloni & Putih susu- merah muda \\
Bentuk Sel & Basil \\
Ukuran Sel & $2-4 \mathrm{~mm}$ \\
\hline
\end{tabular}

Sumber: pengamatan secara makroskopis (2019).

Pengamatan bakteri secara makroskopis dilakukan setiap hari selama 72 jam Bakteri Rhizobium diamati untuk mengetahui ciri-ciri makroskopis yang dilakukan setelah bakteri di isolasi pada media YEMA+Congo Red. Hasil dari pengamatan secara makroskopis pada bakteri Rhizobium pada media perlakuan salin bertingkat memiliki ciri-ciri yang sama yaitu berupa bentuk koloninya yang bulat dengan tepian rata dan permukaan cembung. Memiliki warna putih susu yang kental dan tidak dapat di tembus oleh cahaya, hal ini serupa dengan pernyataan Purwaningsih (2010) yang menyatakan bahwa bakteri Rhizobium tidak menyerap warna merah dari media YEMA + Congo Red. Jadi apabila terdapat isolat bakteri berwarna merah maka dapat dipastikan bakteri tersebut bukan Rhizobium.

Bentuk sel dari bakteri Rhizobium adalah batang atau basil dengan ukuran sel 3-4 $\mathrm{mm}$ dan merupakan jenis bakteri dengan pertumbuhan cepat, hal ini sesuai dengan pernyataan Fajrin (2017) yang menyatakan bahwa ukuran bakteri $1 \mathrm{~mm}$ merupakan jenis bakteri yang pertumbuhannya lambat, sedangkan untuk ukuran bakteri 2-4 mm merupakan jenis bakteri dengan pertumbuhan cepat. Bakteri Rhizobium merukapan jenis bakteri dengan pertumbuhan cepat karena dapat tumbuh pada 24-120 jam masa inkubasi, sedangkan jenis bakteri dengan pertumbuhan lambat apabila bakteri tumbuh pada rentan waktu 120-168 jam masa inkubasi.

\section{Penentuan Jenis Gram Bakteri}

Pengamatan jenis gram bakteri dilakukan menggunakan pewarnaan gram yang bertujuan untuk mengetahui apakah bakteri tersebut bakteri gram positif atau bakteri gram negatif. Data pengamatan diperoleh dengan cara melakukan gram stanning yang selanjutnya di lakukan pengecekan di bawah mikroskop elektron untuk mengetahui bentuk koloni serta ukuran sel koloni bakteri. Hasil analisa bakteri setalah Gram Stanning pada semua perlakuan adalah semua isolat bakteri merupakan jenis gram negatif yaitu dengan dihasilkannya isolat berwarna merah muda.

Setelah dilakukannya pengecatan dengan pewarnaan gram selanjutnya preparat dilakukan pengecekan pada mikroskop elektron untuk mengetahui bentuk sel bakteri Rhizobium dan ukuran selnya, dan didapatkan hasil yaitu, sel bakteri Rhizobium berbentuk batang (basil) dengan ukuran sel rata-rat 3-4 mm.

Pewarnaan gram dilakukan maksimal 18 jam masa inkubasi pada isolat biakan murni hal ini dilakukan untuk mendapatkan bentuk sel yang sempurna karena apabila terlalu lama dapat merubah bentuk sel nya karena masa inkubasi yang lama.Menurut Irfan (2014) mekanisme pewarnaan gram pada bakteri didasarkan pada struktur dan komposisi dinding sel. Pada dinding sel bakteri gram negatif memiliki dinding sel yang tipis sehingga apabila mendapatkan perlakuan 
penyiraman alkohol mengakibatkan dinding sel terekstraksi sehingga permeabilitas nya membesar sehingga warna ungu dari reagent kristal violet mengalami ekstraksi yang menyebabkan hilangnya warna ungu tersebut, dan sebaliknya dinding sel akan menyerap warna kuning dari reagent safranin. Sedangkan untuk jenis bakteri gram positif memiliki dinding sel yang tebal sehingga saat pemberian alkohol dinding sel mengalami dehidrasi yang menyebabkan bentuk sel mengecil dan permeablitasnya berkurang sehingga warna biru dari reagent kristal violet tidak dapat terekstrasi dan tidak dapat menyerap warna dari safranin.
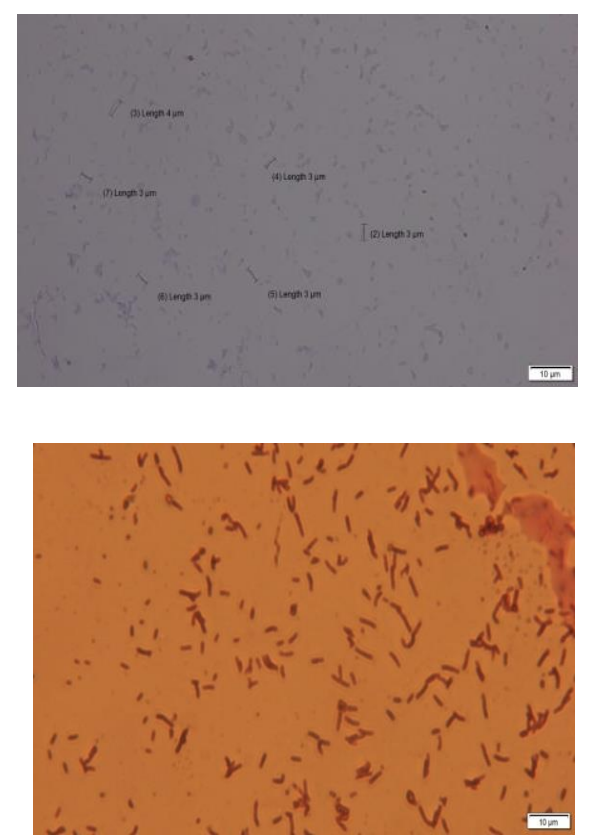

Gambar 3. Bakteri Gram Negatif Dengan Perbesaran 1000X

\section{KESIMPULAN}

Ditemukannya isolate bakteri yang dapat tumbuh pada media dengan cekaman salinitas bertingkat mulai dari 0 ppm, 1000 ppm, 2500 ppm, 4000 ppm, dan 8000 ppm.Karakteristik bakteri Rhizobium japonicum pada cekaman salinitas bertingkat memiliki penampakan morfologi yang sama yaitu, koloni berbentuk bulat cembung, berwarna putih sampai merah muda, dengan tekstur lengket, selnya berbentuk basil dengan ukuran $3 \mu-4 \mu$.

\section{DAFTAR PUSTAKA}

Alihamsyah, T. (2014). Prospek Pengembangan dan Pemanfaatan Lahan Pasang Surut Dalam Prespektif Eksplorasi Sumber Pertumbuhan Pertanian Masa Depan.

Aini, N., Sumiya, W. D. Y., Syekhfani, D. R., \& Setiawan, A. (2014). Kajian pertumbuhan, kandungan klorofil dan hasil beberapa genotipe tanaman kedelai (Glycine max L,) pada kondisi salinitas. In Prosiding Seminar Nasional Lahan Sub Optimal; Palembang (Palembang, 26-27 September 2014) (pp. 591597).

Badan Pusat Statistik. 2016. Luas Panen, Produksi dan Produktivitas Tanaman Kedelai, 2008-2015 di Kabupaten Bayuwangi.

Bloemberg, G. V, \& Lugtenberg, B. J. J. (2001). Molecular basis of plant growth promotion and biocontrol by rhizobacteria, 343-350.

Fajrin, V.N., I. Erdiansyah, and Damanhuri. 2017. Koleksi dan Identifikasi Bakteri Penambat N pada Pusat Lokasi Tanaman Kedelai Edamame (Glycine max (L.) Merr.) di Kabupaten Jember. Agriprima, Journal of Applied Agricultural Sciences, 1(2). pp.143-153. Available at: https://doi.org/10.25047/agriprima. v1i2.35.

Fuskhah, E., Anwar, S., Purbajanti, E. D., Soetrisno, R. D., Budhi, S. P. S., \& Maas, A. (2007). Terhadap 
Salinitas Dan Kemampuan Berasosiasi [ Exploration and Selection of Rhizobium Resistance to Salinity and Its Association with Legume ], 179-185.

Irfan, M. (2014). Isolasi dan enumerasi bakteri tanah gambut di perkebunan kelapa sawit pt. tambang hijau kecamatan tambang kabupaten kampar, 5(1), 1-8.

Purwaningsih, S. (2010). Isolasi, Populasi, dan Karakterisasi Bakteri Rhizobium pada Daerah Perakaran dan Tanah dari Bengkulu, Sumatra. Majalah Ilmiah Biologi BIOSFERA: A Scientific Journal, 27(1), 48-52. 